\title{
Changes in behavioural responses to infrastructure affect local and regional connectivity - a simulation study on pond breeding amphibians
}

\author{
Maj-Britt Pontoppidan', Gösta Nachman' \\ I Section for Ecology and Evolution, Department of Biology, University of Copenhagen, Universitetsparken 15, \\ DK-2100 Copenhagen \\ Corresponding author: Maj-Britt Pontoppidan (mbp@bio.ku.dk) \\ Academic editor: D. Schmeller | Received 30 December 2012 | Accepted 1 April 2013 | Published 13 November 2013 \\ Citation: Pontoppidan M-B, Nachman G (2013) Changes in behavioural responses to infrastructure affect local and \\ regional connectivity - a simulation study on pond breeding amphibians. Nature Conservation 5: 13-28. doi: 10.3897/ \\ natureconservation. 5.4611
}

\begin{abstract}
An extensive and expanding infrastructural network destroys and fragments natural habitat and has detrimental effect on abundance and population viability of many amphibian species. Roads function as barriers in the landscape. They separate local populations from each other or prevent access to necessary resources. Therefore, road density and traffic intensity in a region may have severe impact on regional as well as local connectivity. Amphibians may be able to detect and avoid unsuitable habitat. Individuals' ability to avoid roads can reduce road mortality but at the same time road avoidance behaviour, can increase the barrier effect of the road and reduce connectivity. We use an individual based model to explore how changes in road mortality and road avoidance behaviour affect local and regional connectivity in a population of Moor frogs (Rana arvalis). The results indicate that road mortality has a strong negative effect on regional connectivity, but only a small effect on local connectivity. Regional connectivity is positively affected by road avoidance and the effect becomes more pronounced as road mortality decreases. Road avoidance also has a positive effect on local connectivity. When road avoidance is total and the road functions as a $100 \%$ barrier regional connectivity is close to zero, while local connectivity exhibit very elevated values. The results suggest that roads may affect not only regional or metapopulation dynamics but also have a direct effect on local population dynamics.
\end{abstract}

\section{Keywords}

Rana arvalis, Individual based modelling, Road avoidance, Road mortality, Connectivity, Pond breeding amphibians

Copyright M.-B. Pontoppidan, G. Nachman. This is an open access article distributed under the terms of the Creative Commons Attribution License 3.0 (CC-BY), which permits unrestricted use, distribution, and reproduction in any medium, provided the original author and source are credited. 


\section{Introduction}

All over the world, amphibian populations are declining and many amphibian species are listed in the IUCN as threatened or vulnerable (IUCN 2012). The causes for the decline are hypothesized to be (combinations of) factors such as climate change, diseases, predation and UV-radiation. But the main factor, especially in the western world, is thought to be the increasing urbanisation (Alford and Richards 1999; Beebee and Griffiths 2005; Collins and Storfer 2003; Gardner et al. 2007). The negative effect of urbanisation is not only due to changes in land use and destruction of habitat. A huge infrastructural network functions as barriers to movement and causes the death of a huge number of amphibians every year (Andrews et al. 2008; Hamer and McDonnell 2008). Road density in an area as well as traffic density on individual roads have been shown to have a negative effect on amphibian populations (Eigenbrod et al. 2009; Fahrig and Rytwinski 2009; Hels and Buchwald 2001; Reh and Seitz 1990; Vos and Chardon 1998). Veysey et al. (2011) even found road density to have a stronger effect on population size than habitat availability, while Carr and Fahrig (2001) found more vagile species to be more vulnerable to road mortality.

Very little literature exists on amphibians' reactions to roads. The only study on this topic did not find any indication of road avoidance in Rana pipiens (Bouchard et al. 2009) and the large number of road kills (Elzanowski et al. 2009) suggests a low degree of road avoidance. However, amphibians are able to recognise and avoid unsuitable habitat. Although there are species specific variations, individuals tend to prefer more shady and moist habitat types (Mazerolle 2005; Mazerolle and Desrochers 2005; Popescu and Hunter 2011; Vos et al. 2007). In more open and dry habitats like fields and clear-cuts, water loss is bigger and survival lower resulting in avoidance of such habitats (Rothermel and Semlitsch 2002; Todd and Rothermel 2006). Individuals also tend to move more quickly in inhospitable habitats (Hartung 1991; Tramontano 1997). Traffic-associated stimuli as light and noise can affect amphibian behaviour (Mazerolle et al. 2005) and other species as snakes and salamanders exhibit road avoidance behaviour (Andrews and Whitfield Gibbons 2005; Madison and Farrand 1998). These observations suggest that amphibian movement and behaviour can be affected by roads.

Pond breeding amphibians require both terrestrial and aquatic habitat to complete their life cycle. Proximity between the required habitat types is important for the survival of the population. Loss of, or diminished access to, one or both habitats will affect population size and persistence probability (Dunning et al. 1992; Haynes et al. 2007; Johnson et al. 2007; Pope et al. 2000). Moreover, populations of pond-breeding amphibians are frequently considered to be structured as a regional network or a metapopulation, making dispersal between subpopulations essential to regional population persistence (Hels 2002; Marsh 2008; Marsh and Trenham 2001; Smith and Green 2005). Thus the barrier effect caused by roads may have severe consequences for populations of pond breeding amphibians.

We have developed an individual based model to assess the effects of infrastructure on landscape connectivity. The model is part of a larger study concerning road effects 
on regional populations of Moor frogs (Rana arvalis). In this paper we present our model and explore how behavioural responses to infrastructure may affect local and regional connectivity. The ability to avoid roads may diminish the amount of road kills. This behaviour will prevent dispersal across the road but at the same time it may affect connectivity locally. Lower levels of road avoidance can reduce the road's barrier effect but this will probably depend on the level of road mortality. We hypothesize that

- $\quad$ Regional connectivity will be inhibited by high levels of road avoidance and high road mortality and will depend on interactions between the degree of road avoidance and road mortality.

- Local connectivity will be promoted by high levels of road avoidance but not be affected by road mortality.

We use a real Danish landscape with a population of Moor frogs (Rana arvalis) traversed by a large road to test how regional and local connectivity are affected by changes in road mortality and road avoidance.

\section{Methods}

We use an individual based model to simulate the movements of juvenile Moor frogs and estimate immigration probabilities between habitat patches. The purpose of the model is to measure the connectivity of the landscape. In the following we use the terms dispersal and migration as defined by Semlitsch (2008), i.e. dispersal is "interpopulational, unidirectional movements from natal sites to other breeding sites" and migration is "intrapopulational, round-trip movements toward and away from aquatic breeding sites". The habitat of pond breeding amphibians as the Moor frog includes terrestrial as well as aquatic habitat. Therefore we define the habitat patch of a subpopulation as a complementary habitat patch containing not only the breeding pond but also all accessible summer habitat within migration distance from the pond (Dunning et al. 1992; Pope et al. 2000).

\section{Model species}

Moor frogs spend most of their life in terrestrial habitat; aquatic habitat is only used during the breeding season, which takes place in the early spring (Elmberg 2008; Glandt 2008; Hartung 1991). Soon after breeding, the frogs return to the summer habitat, which lies mostly within a $400 \mathrm{~m}$ radius from the breeding pond (Elmberg 2008; Hartung 1991; Kovar et al. 2009). Adult frogs show a high degree of site fidelity and often use the same breeding pond and summer habitat from year to year (Loman 1994). Long distance dispersal in Moor frogs takes place predominantly during the juvenile life-stage (Semlitsch 2008; Sinsch 1990; 2006). Shortly after metamorphosis, the young 
frogs leave the natal pond and disperse into the surrounding landscape seeking out suitable summer habitat. Dispersal distances are between a few hundred meters up to 1-2 kilometres (Baker and Halliday 1999; Hartung 1991; Sinsch 2006; Vos and Chardon 1998). The juveniles stay in terrestrial habitat 2-3 years until they reach maturity, although some observations indicate that juvenile frogs follow the adults during the spring migration, without entering the breeding ponds (Hartung 1991; Sjögren-Gulve 1998).

\section{Model overview}

Full model documentation following the ODD-template suggested by Grimm et al. $(2006 ; 2010)$ as well as model parameterisation is provided in Appendix in the supplementary material. Netlogo v.4.1.3 (Wilensky 1999) is used as modelling environment (freely downloadable at http://ccl.northwestern.edu/netlogo).

The model considers a regional population of Moor frogs within a spatially explicit landscape matrix. The landscape is constructed from a $600 \times 800$ cell GIS raster map, each cell representing an area of $10 \times 10$ meters. A raster cell is characterised by a set of variables defining the habitat type and its value in regard to the different aspects of the life cycle and behaviour of the Moor frog (Table 1). Potential sites for subpopulations of Moor frogs are represented by a GIS point-data set of ponds surveyed during field work. Each pond is defined by an ID-number, a quality index and the summer habitat fragments located within migration distance from the pond (Table 1).

Immigration requires two events: 1) the successful dispersal of a juvenile frog to summer habitat outside its natal habitat patch and 2) subsequent successful migration from the new summer habitat to a nearby breeding pond. In real life dispersal starts just after metamorphosis in early summer and lasts until hibernation in the autumn. The second part of the immigration event, migration, takes place in the spring 2.5 years later. For simplicity, we simulate the dispersal and breeding migration, as if they take place in the same year.

The time step of the model is one day and the simulated period for dispersal as well as migration is 120 days each. At the start of a simulation, 500 frog agents are created at each pond. Each agent is assigned a random direction, which determines its preferred direction of movement. This direction does not change unless summer habitat is found. At each time step, a random daily travelling distance is chosen for each agent; the distance depending on the attractiveness of the current habitat. The distance is travelled one cell at a time. Depending on the relative attractiveness of the neighbouring cells, frog agents move to one of the cells, although backwards movement is not allowed. The movement rules generate a biased random walk away from the natal pond and in the preferred direction. During dispersal, frog agents encountering a cell with summer habitat will have a certain probability of settling in the habitat and stop dispersing. This probability will increase with time. At the end of the dispersal period all frog agents that have not settled in summer habitat are removed. Starting the migration phase, the remaining frog agents move toward the breeding pond associated 
Table I. List of variables characterizing the agents in the model.

\begin{tabular}{c|c|c|c|c}
\hline Variable & Notation & $\begin{array}{c}\text { Value } \\
\text { range }\end{array}$ & $\begin{array}{c}\text { Agent } \\
\text { type }\end{array}$ & Description \\
\hline DailySurvival & $D_{s}$ & & Cell & Daily survival probability \\
\hline HabitatAttraction & $H_{a}$ & $1-5$ & Cell & The cell's relative attraction to frogs during movement \\
\hline HabitatCode & $H_{c}$ & & Cell & Cell code for habitat type \\
\hline HabitatSurvival & $H_{c}$ & $1-5$ & Cell & The cell's relative survival index \\
\hline SummerQuality & $H_{q}$ & $1-5$ & Cell & The cell's relative suitability as summer habitat \\
\hline BreedingPond & & & Frog & Breeding pond of frog agent \\
\hline NatalPond & & & Frog & Natal pond of frog agent \\
\hline PondID & & & Pond & ID number \\
\hline PondQuality & $Q$ & $0.1-1$ & Pond & Quality index of the pond \\
\hline SummerHabitat & $A$ & & Pond & Summer habitat cells associated with the pond \\
\hline
\end{tabular}

with their summer habitat; in case several breeding ponds are available one is chosen randomly weighted by pond quality. After each time step, the survival probability of every frog agent is assessed, based on the daily survival rates associated with the habitat type traversed during the day.

\section{Input data}

We use GIS data sets from a road project in Denmark, supplied by the Danish Road Directorate and Amphi Consult. The project concerns an area in north-western part of Zealand, $10 \mathrm{~km}$ east of the city of Kalundborg $\left(55^{\circ} 40.14^{\prime} \mathrm{N}, 11^{\circ} 17.85^{\prime} \mathrm{E}\right)$ (Fig. 1). The area is characterised as semi-urban and agricultural landscapes, traversed by creeks and wetlands. A project data set contains a land cover map of the area and a point-data set of potential breeding ponds found during field surveys. The land cover maps are constructed following a protocol designed by amphibian experts (Hassingboe et al. 2012), in which a range of different habitat types are identified. Each habitat type has been assessed and ranked on a scale from 1-5, for the following three variables: the habitat's relative suitability as summer habitat $\left(H_{q}\right)$, its relative attraction to frogs during movement $\left(H_{a}\right)$ and the relative survival probability $(H)$ in the habitat. In the model the survival index $\left(H_{s}\right)$ is converted into a daily survival probability $\left(D_{s}\right)$ (see Appendix for details). Infrastructural elements like roads and railways are processed as any other habitat type and assigned values of habitat attraction and daily survival. However, in the literature the terms "road avoidance" and "road mortality" are more commonly used. To avoid confusion when discussing these effects, we therefore convert $\left(H_{a}\right)$ and $(D)$ to road avoidance $\left(R_{a}\right)$ and road mortality $\left(R_{d}\right)$, respectively, and invert the ranking, i.e. $R_{a}=6-H_{a}$ and $R_{d}=1-D_{s}$.

The point-data set contains information on the location of the potential breeding pond, its ID-number as well as a quality index $(Q)$. Pond qualities ranges from $0.1-1$ and relates to the suitability of the pond and the immediate surroundings in regard to 


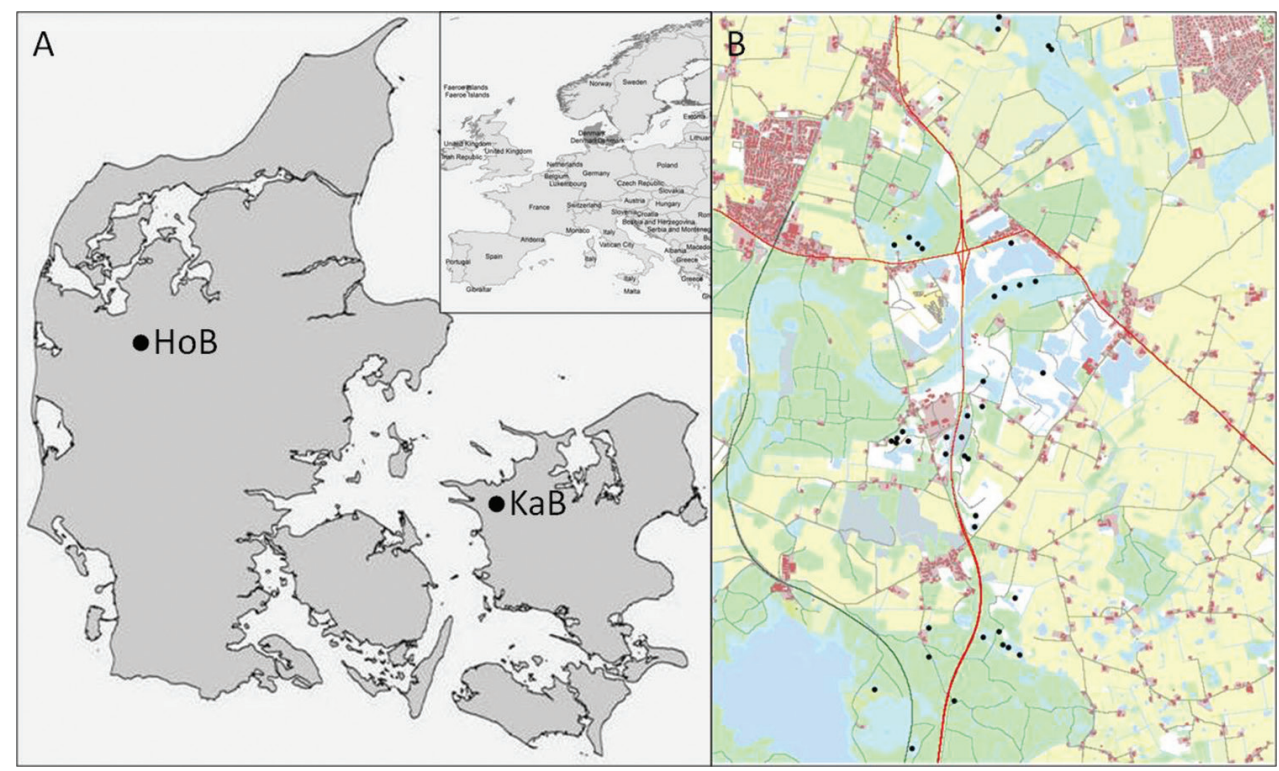

Figure I. Study area. A Location of two study areas in Denmark. KaB is an area near Kalundborg on Zealand and $\mathrm{HoB}$ is near Holstebro in Jutland. Only $\mathrm{KaB}$ is used in the present analysis, but both areas are used for the parameterisation of the model $\mathbf{B ~} \mathrm{KaB}$ map used in the analysis. Black dots are breeding ponds, test roads are marked with red.

egg and larval survival and are estimated by experts during field work. In this paper we have excluded low-quality ponds $(Q<0.6)$, since they per definition have a low probability of maintaining a population on their own. The extent of the map is $6 \times 8 \mathrm{~km}$ and it contains 40 ponds.

\section{Scenarios}

We create scenarios with increasing values of road avoidance, $R_{a}=[1 ; 2 ; 3 ; 4 ; 5]$, and road mortality, $R_{d}=[0.1 ; 0.3 ; 0.5 ; 0.7 ; 0.9]$, of the two major roads cutting through the map (Fig.1, roads shown in red). We run 25 simulations for every combination of the parameter values of $R_{a}$ and $R_{d}$. As $R_{a}$ increases the willingness of the frog agents to enter the road will decrease, while the probability of surviving will increase with decreasing values of $R_{d^{*}}$

\section{Output}

At the end of each simulation, the natal pond and the breeding pond of all frog agents are registered and immigration probability $\left(p_{i j}\right)$ between all pair-wise ponds is calculated. Landscape connectivity $(S)$ is then found as 
$S=\sum_{i=1}^{n} \sum_{j=1}^{n} p_{i j}, \quad(i \neq j)($ eq. 1$)$

Local populations are identified by grouping ponds into clusters depending on their mutual connectivity, using the method of unweighted, arithmetic, average clustering as described by Legendre and Legendre (1998). Since, immigration probabilities between any two ponds are not necessarily symmetric, i.e. $p_{i j} \neq p_{j i}$, we use summed immigration probabilities as similarity measure $(m): m_{i j}=p_{i j}+p_{j i}$. The threshold at which a given pond or cluster no longer can be added to another cluster is set to $m_{i j} \leq 0.01$. We define local connectivity as the connectivity within a cluster and regional connectivity is defined as the connectivity between all pair-wise combinations of clusters. Based on the clustering result we compute within-cluster connectivity $\left(S_{c}\right)$ for each cluster as

$S_{c}=\sum_{i=1}^{n_{c}} \sum_{j=1}^{n_{c}} p_{i j}, \quad(i \neq j) \quad($ eq. 2$)$

where $n_{c}$ is the number of ponds belonging to cluster $c$. Connectivity between clusters $\left(S_{b}\right)$ is then found as $S_{b}=S-S_{c}$. However, to be able to detect changes in local connectivity, the ponds constituting a cluster must be the same in all scenarios. Therefore, we use the cluster configuration found when $R_{a}$ is set to 5 to define clusters, and use this in all calculations of within-cluster connectivity.

We use a multiple regression model, with the general form $y=\beta_{0}+\beta_{1} R_{d}+\beta_{2} R_{a}$ $+\beta_{3} R_{d} R_{a}+\varepsilon$., to test for the effect of road avoidance $\left(R_{a}\right)$, road mortality $\left(R_{d}\right)$ and their interaction on landscape connectivity $(S)$, within-cluster connectivity $(S)$ and between-cluster connectivity $\left(S_{b}\right)$. Sequential Holm-Bonferroni correction is used to adjust p-values. When $R_{a}$ is set to 5 , frog agents to do not enter the road, therefore the level of road mortality is inconsequential. Moreover, preliminary tests showed extreme connectivity values when the road is $100 \%$ blocked. Both of these factors risk masking the statistical effect of road mortality and road avoidance on connectivity at other levels of $R_{a}$. Consequently, the results from the scenarios with $R_{a}=5$ are excluded from the statistical testing.

\section{Results}

Analyses of the scenarios with $R_{a}=5$ identify seven clusters (Fig. 2A, Table 2). Cluster $\mathrm{cl}$ contains four ponds and is located rather remotely in the top of the map. Clusters c2 and $\mathrm{c} 3$ are found in areas close to where the two test roads cross and contains four, respectively, five ponds. Cluster $\mathrm{c} 4$ and cluster $\mathrm{c} 5$ contains seven and nine ponds, respectively. These are more widespread clusters situated on either side of the road in the middle of the map. The last two clusters c 6 and $\mathrm{c} 7$ are placed near the bottom of the map and contain two and six ponds. As described in the method section we use this cluster configuration as a reference for all scenarios when calculating within-cluster connectiv- 


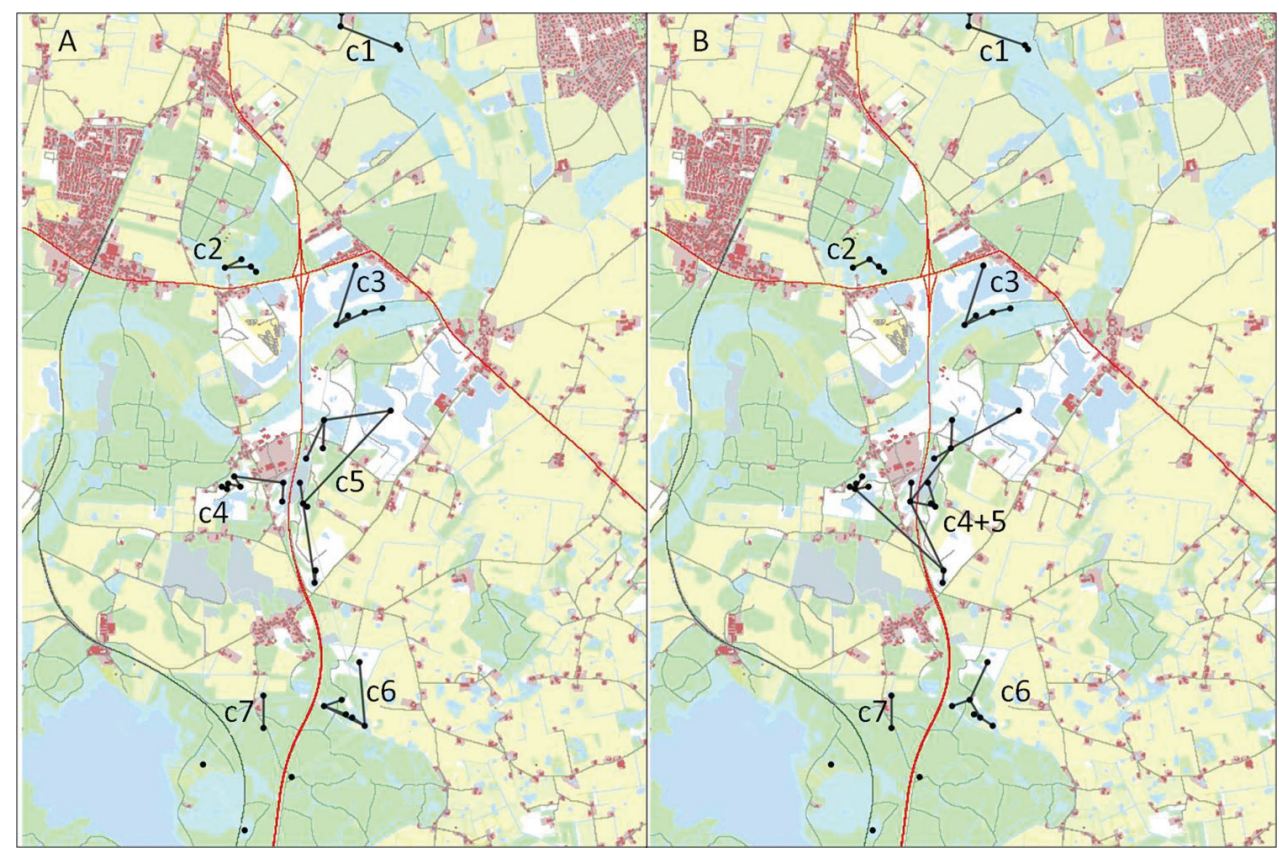

Figure 2. Results from cluster analyses with two different parameter settings. A $R_{a}=5, R_{d}=0.1$ and B $R_{a}=4, R_{d}=0.1$.

Table 2. Descriptive statistics of the identified clusters. The cluster's ID, number of ponds in the cluster, mean distance from the ponds to a road, the distance to the pond closest to the road and the number of pond members no more than $200 \mathrm{~m}$ from the road. Furthermore it is shown whether the cluster exhibits extreme connectivity values when $R_{a}=5$, its response to road avoidance and its response to road mortality.

\begin{tabular}{c|c|c|c|c|c|c|c}
\hline \multirow{2}{*}{ Cluster Id } & \multicolumn{4}{|c|}{ Cluster characteristics } & \multicolumn{3}{|c}{ Respons patterns } \\
\cline { 2 - 8 } & Cluster size & $\begin{array}{c}\text { Mean distance } \\
(\mathbf{m})\end{array}$ & $\begin{array}{c}\text { Min distance } \\
(\mathbf{m})\end{array}$ & $\begin{array}{c}\text { Ponds } \\
\mathbf{2 0 0 m}\end{array}$ & $\boldsymbol{R}_{\boldsymbol{a}} \mathbf{= 5}$ & Avoidance & Mortality \\
\hline $\mathrm{c} 1$ & 4 & 1322 & 1082 & 0 & $\mathrm{~N}$ & $\mathrm{~N}$ & $\mathrm{~N}$ \\
\hline $\mathrm{c} 2$ & 4 & 184 & 110 & 3 & $\mathrm{Y}$ & $\mathrm{Y}$ & $\mathrm{N}$ \\
\hline $\mathrm{c} 3$ & 5 & 345 & 76 & 1 & $\mathrm{Y}$ & $\mathrm{Y}$ & $\mathrm{N}$ \\
\hline $\mathrm{c4}$ & 7 & 431 & 61 & 2 & $\mathrm{Y}$ & $\mathrm{Y}$ & $\mathrm{Y}$ \\
\hline $\mathrm{c5}$ & 9 & 223 & 71 & 6 & $\mathrm{Y}$ & $\mathrm{Y}$ & $\mathrm{Y}$ \\
\hline $\mathrm{c6}$ & 6 & 323 & 98 & 1 & $\mathrm{Y}$ & $\mathrm{N}$ & $\mathrm{N}$ \\
\hline $\mathrm{c7}$ & 2 & 385 & 318 & 0 & $\mathrm{~N}$ & $\mathrm{~N}$ & $\mathrm{~N}$ \\
\hline
\end{tabular}

ity. Nonetheless, the analyses show that cluster configurations do not change with the different scenarios except when road mortality is set to 0.1 . In this case dispersal success is sufficiently high between cluster $\mathrm{c} 4$ and $\mathrm{c} 5$ and they fuse into one cluster (Fig. 2B).

When $R_{a} \leq 4$, road mortality has strong negative effect on the connectivity between clusters $\left(S_{b}\right)$ while road avoidance has a positive effect. Furthermore, there is an interaction effect; the effect of road avoidance becomes more pronounced as road 
Table 3. Statistical results of multiple regression models. Statistical significance of variables and interactions in multiple regressions on landscape connectivity $(S)$, within-cluster connectivity $(S)$ of cluster c1 - c7 and between-cluster connectivity $\left(S_{b}\right)$. Sequential Holm-Bonferroni correction is used to adjust p-values. Statistically significant values are shown in bold.

\begin{tabular}{|c|c|c|c|c|c|c|c|c|c|c|}
\hline \multirow{2}{*}{ Dependent factor } & \multirow{2}{*}{ df } & \multicolumn{3}{|c|}{ Full model } & \multicolumn{2}{|c|}{ Road mortality $\boldsymbol{R}_{d}$} & \multicolumn{2}{|c|}{ Road avoidance, $R_{a}$} & \multicolumn{2}{|c|}{ Interaction $\boldsymbol{R}_{a}^{*} \boldsymbol{R}$} \\
\hline & & $F$ & $p$ & $\mathbf{R}^{2}$ & Parameter & $p$ & Parameter & $p$ & Parameter & $p$ \\
\hline$S_{c 1}$ & 496 & 0.30 & 0.82 & 0.002 & -0.003 & 0.873 & 0.001 & 0.738 & 0.001 & 0.884 \\
\hline$S_{c 2}$ & 496 & 7.20 & $<0.001$ & 0.042 & 0.018 & 0.281 & 0.012 & $<0.001$ & -0.014 & 0.018 \\
\hline$S_{c 3}$ & 496 & 39.31 & $<0.001$ & 0.192 & -0.024 & 0.240 & 0.021 & $<0.001$ & -0.020 & 0.007 \\
\hline$S_{c 4}$ & 496 & 255.1 & $<0.001$ & 0.607 & -0.053 & 0.014 & 0.064 & $<0.001$ & -0.012 & 0.121 \\
\hline$S_{c 5}$ & 496 & 487.9 & $<0.001$ & 0.747 & -0.094 & $<0.001$ & 0.092 & $<0.001$ & -0.006 & 0.522 \\
\hline$S_{c \sigma}$ & 496 & 0.85 & 0.45 & 0.005 & -0.014 & 0.496 & 0.002 & 0.739 & 0.002 & 0.775 \\
\hline$S_{c 7}$ & 496 & 0.81 & 0.49 & 0.005 & -0.005 & 0.584 & 0.001 & 0.676 & 0.0001 & 0.976 \\
\hline$S_{b}$ & 496 & 1814 & $<0.001$ & 0.917 & -0.831 & $<0.001$ & 0.114 & $<0.001$ & -0.096 & $<0.001$ \\
\hline$S$ & 496 & 1297 & $<0.001$ & 0.887 & -1.005 & $<0.001$ & 0.307 & $<0.001$ & -0.145 & $<0.001$ \\
\hline
\end{tabular}
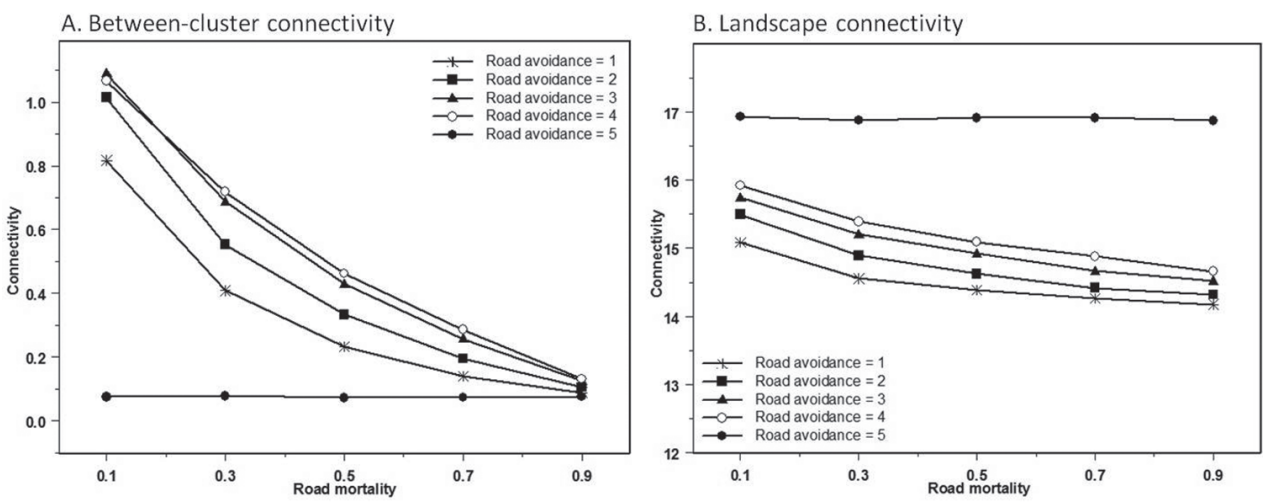

Figure 3. Effect of road avoidance $\left(R_{a}\right)$ and road mortality $\left(R_{d}\right)$ on $\mathbf{A}$ between-cluster connectivity $\left(S_{b}\right)$ and $\mathbf{B}$ landscape connectivity $(S)$.

mortality decreases (Table 3$)$. These effects are all statistically significant $\left(\mathrm{F}_{3,496}=1814\right.$, $\mathrm{p}<0.001$ ). When $R_{a}=5$, between-cluster connectivity yields its lowest values (Fig. 3A). In these scenarios all dispersal across the road is impossible. Hence, the measured connectivity must represent the connectivity between clusters on the same side of the road.

Overall landscape connectivity $(S)$ exhibits very elevated values when road avoidance is total. Otherwise, landscape connectivity decreases with road mortality and increases with road avoidance, the effect of road avoidance being strongest at lower values of road mortality (Fig. 3B). All effects are statistically significant $\left(\mathrm{F}_{3,496}=1297\right.$, $\mathrm{p}<0.001$ ) (Table 3).

In general, the same trends are found in within-cluster connectivity $\left(S_{c}\right)$ (Table 3). There are, however, some differences. Within-cluster connectivity of cluster $\mathrm{cl}$ and $\mathrm{c} 7$ is affected neither by changes in road mortality nor road avoidance. These two clusters are also furthest away from the test roads (Table 2). Clusters c2 trough c6 all exhibit 

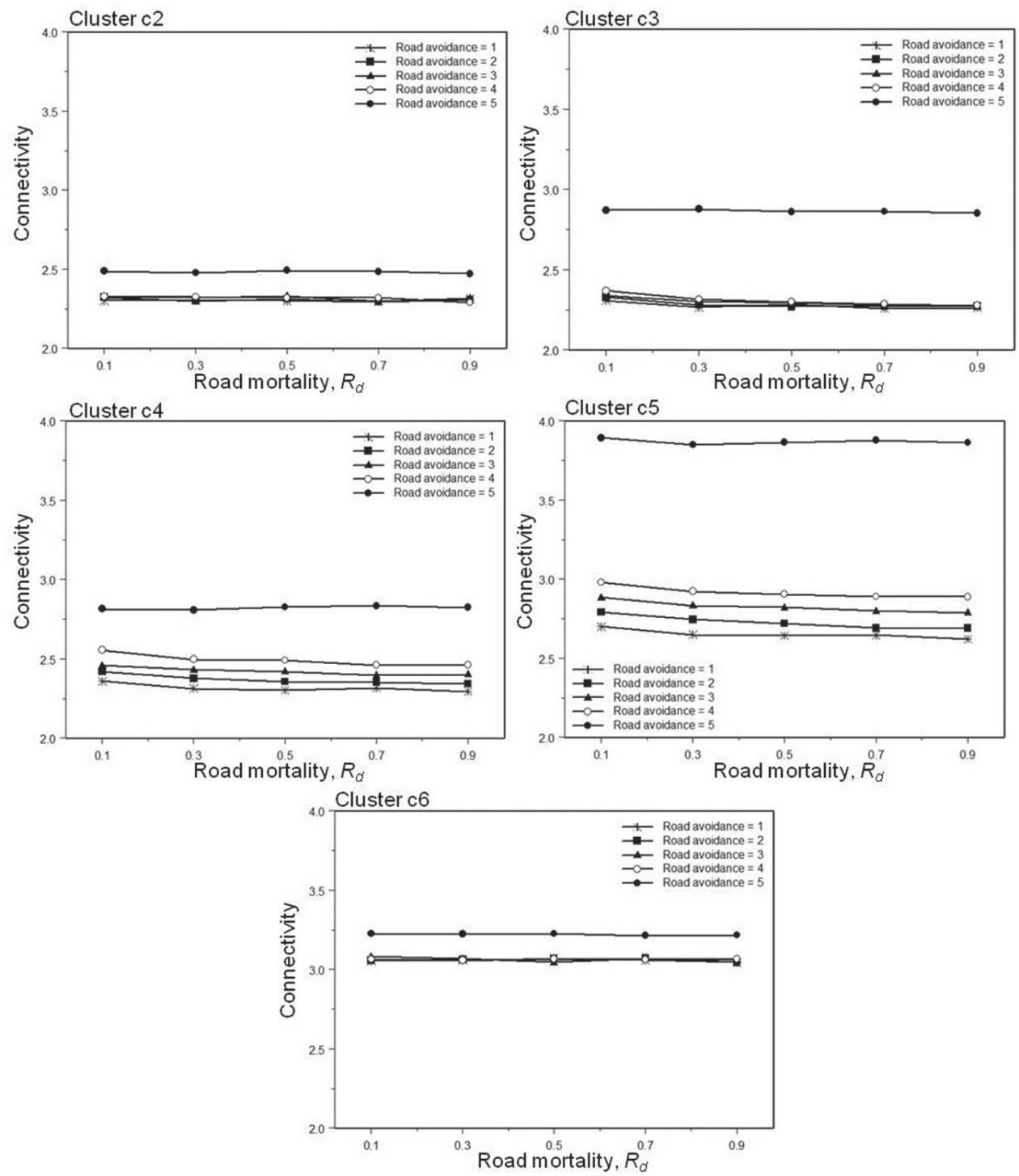

Figure 4. Effect of road avoidance $\left(R_{a}\right)$ and road mortality $\left(R_{d}\right)$ on within-cluster connectivity $\left(S_{c}\right)$ in cluster $c 2-c 6$.

very elevated connectivity values when $R_{a}=5$. Connectivity within these clusters also tend to increase with road avoidance and decrease with road mortality when $R_{a} \leq 4$ (Fig. 4). However, the effect of road mortality is only statistically significant in clusters c4 and c5 (and after Bonferroni correction only c5). Both are large clusters with several pond members very close to the road (Table 2 , Table 3 ). Clusters c2 - c5 are all significantly affected by road avoidance; in contrast to $c 6$ in which the majority of member ponds are further away from the road (Table 2, Table 3). 


\section{Discussion}

As hypothesized road mortality has a negative effect on between-cluster connectivity. However, contrary to our expectation we find that road avoidance can promote connectivity across roads. An explanation could be that roads actually functions as traps if road avoidance is low. In this model roads are not just lines to cross; they are considered the same way as other kinds of habitat. Hence, when habitat attraction of the roads is higher (and thus road avoidance low) than the surrounding habitat, the road may actually be the preferred habitat. Moreover, the survival probability on roads is always lower than in any other type of habitat. Thus, at high levels of road avoidance, frog agents only rarely enter the roads, but if they do they quickly leave it again and only suffer the high mortality for at short time. When road avoidance is low, frog agents enter the roads more willingly and will tend to stay there, suffering from the higher mortality for a longer time. The severity of the "trap" effect will depend on road mortality as, all else being equal, successful dispersal across the road depends on the survival probability. The results do in fact show a strong interaction; the positive effect of road avoidance on between-cluster connectivity getting more pronounced as road mortality increases.

In accordance with our second hypothesis, we find that road avoidance has a positive effect on local connectivity. In particular, when road avoidance is set to five, connectivity shows considerable elevated values. The strong effect on within-cluster connectivity of a $100 \%$ barrier may seem surprising, but can be explained as a "deflection" effect. When the road is inaccessible road mortality is no longer an issue and a larger proportion of frog agents will survive. Moreover, the blockage forces the agents to move along the road instead of crossing. Taken together, this has the effect that a larger proportion of frog agents stays within the local area for a longer time, which increases the probability of an agent settling within the cluster, enhancing within-cluster connectivity. We did not expect road mortality to have an effect on within-cluster connectivity, but we do find a negative, although week, response. This is probably because there will be a small proportion of frog agents entering the road and returning to the same side. The survival probability of these returnees will depend on road mortality.

The seven clusters identified in this study do not all respond in the same way to changes in road avoidance and road mortality. Two of the clusters, $c 1$ and c7, are not affected at all; these are also the clusters furthest away from the road. Road mortality only significantly affects larger clusters with several pond members very close to the road; maybe because only these clusters have sufficient number of returnees for the effect to be detectable. Road avoidance, on the other hand, affects also clusters further away; only clusters with a minimum distance to road above $300 \mathrm{~m}$ are unaffected by road avoidance. The result suggests that if the road is within the summer habitat of some of the member ponds, then road avoidance will affect within-cluster connectivity.

In this study, scenarios with road avoidance set to five, correspond to real life situations where fencing along roads prevents access to the road. Our results suggest that fencing can result in highly increased local connectivity, even between ponds not in 
immediate proximity to the road. Thus, fencing may not just mitigate road induced mortality but may actually enhance local population persistence. However, the results also show this to be at the cost of regional connectivity. Fencing separates a population into several smaller and more isolated groups of subpopulations, each of which may have a higher risk of extinction and a lower probability of recolonisation. In a simulation experiment with a local population of virtual animals Jaeger and Fahrig (2004) found that fencing could prolong persistence time but had little effect on persistence probability, and in most cases the population only survived on one side of the road. Moreover, studies have shown that gene flow between subpopulation and genetic diversity in a regional population can be reduced by the barrier effect of roads (Arens et al. 2007; Johansson et al. 2005; Reh and Seitz 1990). Thus, whether the positive effect of fencing on landscape connectivity translates into improved population persistence will depend on the number, quality and connectivity between subpopulation on the same side of the road (Hels and Nachman 2002).

The series of scenarios are hypothetical and all may not correspond to real life situations but road mortality can indeed range between very low and very high values, depending on traffic intensity. Extreme low values of road avoidance, to the point where the road becomes more attractive than the surrounding landscape, may seem very unrealistic. However, behavioural responses to traffic like immobilisation (Mazerolle et al. 2005) can have similar effects; and after rain fall wet, dark roads may appear deceptively attractive to frogs (Andrews et al. 2008). Furthermore, the propensity of frogs to enter roads may depend on the property of the road or road verges. Thus, the level of road avoidance may, at least partly, be controlled by the design of the road.

Our study concerns a specific landscape and a specific species, but still it is possible to draw some general conclusion. First of all our results emphasize that connectivity is context dependent. The behaviour of the focal species, the structure of the landscape and their interaction are essential to how connectivity is realized. Furthermore, our simulations indicate that the barrier effect of roads not only affect dispersal across roads. Even between ponds located on the same side of the road, dispersal success can be highly susceptible to road avoidance and road mortality, depending on the distance to the road. This suggests that roads may affect not only regional or metapopulation dynamics but also have a direct effect on local population dynamics.

Very little is known about the effects of mitigation measures in general. Once mitigation measures are implemented, efforts are seldom put into discovering how well they work (Lesbarreres and Fahrig 2012; van der Grift et al. 2013). Simulation studies like the one presented here can provide a means to assess the effects of planned road designs and mitigation measures (van der Ree et al. 2009).

\section{Acknowledgements}

The work was funded by the Danish Road Directorate. The Amphi Consult group has provided amphibian expertise as well as map data. Marianne Ujvári, Martin Hesselsøe, 
Agnete Jørgensen and Martin Schneekloth have given valuable feed-back during the model development. Uta Berger has given precious help during the work and kept the main author on the IBM-track. We are very thankful to Carolyn Bauer for linguistic help. We also thank two anonymous reviewers for insightful comments on the manuscript.

\section{References}

Alford RA, Richards SJ (1999) Global amphibian declines: A problem in applied ecology. Annual Review of Ecology and Systematics 30: 133-165. doi: 10.1146/annurev.ecolsys.30.1.133

Andrews KM, Whitfield Gibbons J (2005) How do highways influence snake movement? Behavioral responses to roads and vehicles. Copeia 2005. doi: 10.1643/0045-8511(2005)005[0772:hdhism]2.0.co;2

Andrews KM, Gibbons JW, Jochimsen DM (2008) Ecological effects of roads on amphibians and reptiles: a literature review. In: Mitchell JC, Jung Brown RE, Bartholomew B (Eds) Urban herpetology. Society for the Study of Amphibians and Reptiles, 121-143.

Arens P, van der Sluis T, van't Westende WPC, Vosman B, Vos CC, Smulders MJM (2007) Genetic population differentiation and connectivity among fragmented Moor frog (Rana arvalis) populations in The Netherlands. Landscape Ecology 22: 1489-1500. doi: 10.1007/ s10980-007-9132-4

Baker JMR, Halliday TR (1999) Amphibian colonization of new ponds in an agricultural landscape. Herpetological Journal 9: 55-63.

Beebee TJC, Griffiths RA (2005) The amphibian decline crisis: A watershed for conservation biology? Biological Conservation 125: 271-285. doi: 10.1016/j.biocon.2005.04.009

Bouchard J, Ford AT, Eigenbrod FE, Fahrig L (2009) Behavioral Responses of Northern Leopard Frogs (Rana pipiens) to Roads and Traffic: Implications for Population Persistence. Ecology and Society 14(2): 23.

Carr LW, Fahrig L (2001) Effect of road traffic on two amphibian species of differing vagility. Conservation Biology 15: 1071-1078.

Collins JP, Storfer A (2003) Global amphibian declines: sorting the hypotheses. Diversity and Distributions 9: 89-98. doi: 10.1046/j.1472-4642.2003.00012.x

Dunning JB, Danielson BJ, Pulliam HR (1992) Ecological processes that affect populations in complex landscapes. Oikos 65: 169-175. doi: 10.2307/3544901

Eigenbrod F, Hecnar SJ, Fahrig L (2009) Quantifying the Road-Effect Zone: Threshold Effects of a Motorway on Anuran Populations in Ontario, Canada. Ecology and Society 14(1): 24.

Elmberg J (2008) Ecology and natural history of the moor frog (Rana arvalis) in boreal Sweden. In: Glandt D, Jehle R (Eds) The Moor Frog Laurenti-Verlag, Bielefeld, 179-194.

Elzanowski A, Ciesiolkiewicz J, Kaczor M, Radwanska J, Urban R (2009) Amphibian road mortality in Europe: a meta-analysis with new data from Poland. European Journal of Wildlife Research 55: 33-43. doi: 10.1007/s10344-008-0211-x

Fahrig L, Rytwinski T (2009) Effects of Roads on Animal Abundance: an Empirical Review and Synthesis. Ecology and Society 14: 21. 
Gardner TA, Barlow J, Peres CA (2007) Paradox, presumption and pitfalls in conservation biology: The importance of habitat change for amphibians and reptiles. Biological Conservation 138: 166-179. doi: 10.1016/j.biocon.2007.04.017

Glandt D (2008) Der Moorfrosch (Rana arvalis): Erscheinungsvielfalt, Verbreitung, Lebensräume, Verhalten sowie Perspectiven für den Artenschutz. In: Glandt D, Jehle R (Eds) The Moor Frog. Laurenti-Verlag, Bielefeld.

Grimm V, Berger U, Bastiansen F, Eliassen S, Ginot V, Giske J, Goss-Custard J, Grand T, Heinz SK, Huse G, Huth A, Jepsen JU, Jorgensen C, Mooij WM, Muller B, Pe'er G, Piou C, Railsback SF, Robbins AM, Robbins MM, Rossmanith E, Ruger N, Strand E, Souissi S, Stillman RA, Vabo R, Visser U, DeAngelis DL (2006) A standard protocol for describing individual-based and agent-based models. Ecological Modelling 198: 115-126. doi: 10.1016/j.ecolmodel.2006.04.023

Grimm V, Berger U, DeAngelis DL, Polhill JG, Giske J, Railsback SF (2010) The ODD protocol: A review and first update. Ecological Modelling 221: 2760-2768. doi: 10.1016/j. ecolmodel.2010.08.019

Hamer AJ, McDonnell MJ (2008) Amphibian ecology and conservation in the urbanising world: A review. Biological Conservation 141: 2432-2449. doi: 10.1016/j.biocon.2008.07.020

Hartung H (1991) Untersuchung zur terrestrischen Biologie von Populationen des Moorfrosches (Rana arvalis NILSSON 1842) unter besonderer Berücksichtigung der Jahresmobilität. Universität Hamburg, Hamburg.

Hassingboe J, Neergaard RS, Hesselsøe M (2012) Manual til produktion af GIS raster kort til:"EDB-værktøj til at vurdere skader på bestande af padder /økologisk funktionalitet". Amphi Consult.

Haynes KJ, Diekotter T, Crist TO (2007) Resource complementation and the response of an insect herbivore to habitat area and fragmentation. Oecologia 153: 511-520. doi: 10.1007/s00442-007-0749-4

Hels T (2002) Population dynamics in a Danish metapopulation of spadefoot toads Pelobates fuscus. Ecography 25: 303-313. doi: 10.1034/j.1600-0587.2002.250307.x

Hels T, Buchwald E (2001) The effect of road kills on amphibian populations. Biological Conservation 99: 331-340. doi: 10.1016/S0006-3207(00)00215-9

Hels T, Nachman G (2002) Simulating viability of a spadefoot toad Pelobates fuscus metapopulation in a landscape fragmented by a road. Ecography 25: 730-744. doi: 10.1034/j.16000587.2002.250609.x

IUCN (2012) IUCN Red List of Threatened Species. Version 2012.2.

Jaeger JaG, Fahrig L (2004) Effects of Road Fencing on Population Persistence. Conservation Biology 18: 1651-1657. doi: 10.1111/j.1523-1739.2004.00304.x

Johansson M, Primmer CR, Sahlsten J, Merilä J (2005) The influence of landscape structure on occurrence, abundance and genetic diversity of the common frog, Rana temporaria. Global Change Biology 11: 1664-1679. doi: 10.1111/j.1365-2486.2005.1005.x

Johnson JR, Knouft JH, Semlitsch RD (2007) Sex and seasonal differences in the spatial terrestrial distribution of gray treefrog (Hyla versicolor) populations. Biological Conservation 140: 250-258. doi: 10.1016/j.biocon.2007.08.010 
Kovar R, Brabec M, Vita R, Bocek R (2009) Spring migration distances of some Central European amphibian species. Amphibia-reptilia 30: 367-378. doi: 10.1163/156853809788795236 Legendre P, Legendre L (1998) Numerical ecology. Elsevier.

Lesbarreres D, Fahrig L (2012) Measures to reduce population fragmentation by roads: what has worked and how do we know? Trends in Ecology \& Evolution 27: 374-380. doi: $10.1016 / j . t r e e .2012 .01 .015$

Loman J (1994) Site tenacity, within and between summers, of Rana arvalis and Rana temporaria. Alytes 12: 15-29.

Madison DM, Farrand L, III (1998) Habitat use during breeding and emigration in radio-implanted tiger salamanders, Ambystoma tigrinum. Copeia 1998: 402-410. doi: $10.2307 / 1447434$

Marsh D (2008) Metapopulation viability analysis for amphibians. Animal Conservation 11: 463-465. doi: 10.1111/j.1469-1795.2008.00223.x

Marsh DM, Trenham PC (2001) Metapopulation dynamics and amphibian conservation. Conservation Biology 15: 40-49.

Mazerolle MJ (2005) Drainage Ditches Facilitate Frog Movements in a Hostile Landscape. Landscape Ecology 20: 579-590. doi: 10.1007/s10980-004-3977-6

Mazerolle MJ, Desrochers A (2005) Landscape resistance to frog movements. Canadian Journal of Zoology-Revue Canadienne De Zoologie 83: 455-464. doi: 10.1139/z05-032

Mazerolle MJ, Huot M, Gravel M (2005) Behavior of amphibians on the road in response to car traffic. Herpetologica 61: 380-388. doi: 10.1655/04-79.1

Pope SE, Fahrig L, Merriam NG (2000) Landscape complementation and metapopulation effects on leopard frog populations. Ecology 81: 2498-2508. doi: 10.1890/0012-9658(2000)081[2498:LCAMEO]2.0.CO;2

Popescu VD, Hunter ML, Jr. (2011) Clear-cutting affects habitat connectivity for a forest amphibian by decreasing permeability to juvenile movements. Ecological Applications 21: 1283-1295. doi: 10.1890/10-0658.1

Reh W, Seitz A (1990) The influence of land-use on the genetic-structure of populations of the common frog Rana-temporaria. Biological Conservation 54: 239-249. doi: 10.1016/00063207(90)90054-S

Rothermel BB, Semlitsch RD (2002) An experimental investigation of landscape resistance of forest versus old-field habitats to emigrating juvenile amphibians. Conservation Biology 16: $1324-1332$.

Semlitsch RD (2008) Differentiating migration and dispersal processes for pond-breeding amphibians. Journal of Wildlife Management 72: 260-267. doi: 10.2193/2007-082

Sinsch U (1990) Migration and orientation in anuran amphibians. Ethology Ecology \& Evolution 2: 65-79. doi: 10.1080/08927014.1990.9525494

Sinsch U (2006) Orientation and navigation in Amphibia. Marine and Freshwater Behaviour and Physiology 39: 65-71. doi: 10.1080/10236240600562794

Sjögren-Gulve P (1998) Spatial movement patterns in frogs: Differences between three Rana species. Ecoscience 5: 148-155. 
Smith MA, Green DM (2005) Dispersal and the metapopulation paradigm in amphibian ecology and conservation: are all amphibian populations metapopulations? Ecography 28: 110-128. doi: 10.1111/j.0906-7590.2005.04042.x

Todd BD, Rothermel BB (2006) Assessing quality of clearcut habitats for amphibians: Effects on abundances versus vital rates in the southern toad (Bufo terrestris). Biological Conservation 133: 178-185. doi: 10.1016/j.biocon.2006.06.003

Tramontano R (1997) Continuous radio tracking of the common frog, Rana temporaria. Herpetologia Bonnensis: 359-365.

van der Grift EA, van der Ree R, Fahrig L, Findlay S, Houlahan J, Jaeger JAG, Klar N, Madrinan LF, Olson L (2013) Evaluating the effectiveness of road mitigation measures. Biodiversity and Conservation 22: 425-448. doi: 10.1007/s10531-012-0421-0

van der Ree R, Heinze D, McCarthy M, Mansergh I (2009) Wildlife Tunnel Enhances Population Viability. Ecology and Society 14(2): 7.

Veysey JS, Mattfeldt SD, Babbitt KJ (2011) Comparative influence of isolation, landscape, and wetland characteristics on egg-mass abundance of two pool-breeding amphibian species. Landscape Ecology 26: 661-672. doi: 10.1007/s10980-011-9590-6

Vos CC, Chardon JP (1998) Effects of habitat fragmentation and road density on the distribution pattern of the moor frog Rana arvalis. Journal of Applied Ecology 35: 44-56. doi: 10.1046/j.1365-2664.1998.00284.x

Vos CC, Goedhart PW, Lammertsma DR, Spitzen-Van der Sluijs AM (2007) Matrix permeability of agricultural landscapes: an analysis of movements of the common frog (Rana temporaria). Herpetological Journal 17: 174-182.

Wilensky U (1999) NetLogo. Center for Connected Learning and Computer-Based Modeling, Northwestern University, Evanston, IL. http://ccl.northwestern.edu/netlogo

\section{Appendix}

Full model description following the ODD-template suggested by Grimm et al. (2006, 2010) and model parameterisation. (doi: 10.3897/natureconservation.5.4611.app). File format: Adobe PDF document (pdf).

Copyright notice: This dataset is made available under the Open Database License (http://opendatacommons.org/licenses/odbl/1.0/). The Open Database License $(\mathrm{ODbL})$ is a license agreement intended to allow users to freely share, modify, and use this Dataset while maintaining this same freedom for others, provided that the original source and author(s) are credited.

Citation: Pontoppidan M-B, Nachman G (2013) Changes in behavioural responses to infrastructure affect local and regional connectivity - a simulation study on pond breeding amphibians. Nature Conservation 5: 13-28. doi: 10.3897/ natureconservation.5.4611.app 